\title{
The Effect of Feed to Inoculums Ratio on Biogas Production Rate from Cattle Manure Using Rumen Fluid as Inoculums
}

\author{
Sunarso $^{\text {I\# }}$, S. Johari", I N. Widiasa ${ }^{*}$, and Budiyono* \\ \# Doctor Program in Animal Agriculture, Post Graduate Program, Diponegoro University, Jl. Imam Bardjo, SH No. 5 Semarang \\ ${ }^{2}$ Department of Chemical Engineering, Faculty of Engineering, Diponegoro University, Jl. Prof. Sudarto, SH No. 1 Semarang \\ Telp. (024) 7460058; Fax. (024) 76480675; \\ ${ }^{1}$ Sunarso_undipeyahoo.com
}

\begin{abstract}
In this study, rumen fluid of animal ruminant was used as inoculums to increase biogas production rate from cattle manure at mesophilic condition. A series of laboratory experiments using $400 \mathrm{ml}$ biodigester were performed in batch operation mode. Given 100 grams of fresh cattle manure was fed to each biodigester and mixed with rumen fluid and tap water resulting five different feed to inoculum (F/I) ratios (i.e. 17.64, 23.51, 35.27, and 70.54). The operating temperatures were varied at room temperature. The results showed that the rumen fluid inoculated to biodigester significantly effected the biogas production. Rumen fluid inoculums caused biogas production rate and efficiency increase more than two times in compare to manure substrate without rumen fluid inoculums. At four F/Is tested, after 80 days digestion, the biogas yield were 191, 162, 144 and $112 \mathrm{~mL} / \mathrm{g} \mathrm{VS}$, respectively. About 80\% of the biogas production was obtained during the first 40 days of digestion. The best performance of biogas production will be obtained if F/I ratio is in the range of 17.64 to 35.27 (correspond to $25-50 \%$ of rumen fluid). The future work will be carried out to study the dynamics of biogas production if both the rumen fluid inoculums and manure are fed in the continuous system.
\end{abstract}

[Keywords - rumen fluid, inoculums, F/I ratio, anaerobic digestion, biogas production]

\section{INTRODUCTION}

Energy is one of the most important factors to global prosperity. The dependence on fossil fuels as primary energy source has lead to global climate change, environmental degradation, and human health problems. In the year 2040, the world predicted will have 9-10 billion people and must be provided with energy and materials (Okkerse and Bekkum, 1999). Moreover, the recent rise in oil and natural gas prices may drive the current economy toward alternative energy sources such as biogas.

Anaerobic digestion (AD) is a technology widely used for treatment of organic waste for biogas production. AD that utilizes manure for biogas production is one of the most promising uses of biomass wastes because it provides a source of energy while simultaneously resolving ecological and agrochemical issues. The anaerobic fermentation of manure for biogas production does not reduce its value as a fertilizer supplement, as available nitrogen and other substances remain in the treated sludge (Alvarez and Lide'n, 2008).

Numerous studies had been conducted by several researchers in order to increase biogas yield in AD. An effort to improve biomass conversion efficiency and biogas yield conducted by several researchers i.e by using two continuously stirred tank reactors (CSTR) in series (Boe, 2006; Kaparaju et al. (2009); selectively retaining the solids within the reactor by holding mixing prior to effluent removal (Kaparaju et al., 2008); pretreatment of manure by separating solids from digested material in order to improve biodegradability and accessibility (Liao et al. (1984; Kaparaju and Angelidaki, 2008; Moller, 2008); and improving bacterial nutritional requirement (Kayhanian and Rich, 1995; Demirci and Demirer. 2004). In addition, an effort to increase biogas yield also has been done by improving contact between bacteria and substrate using stirring (Krylova et al., 1997;
Callaghan et al., 1999; Karim, 2005); immobilizing microbe using fixed film reactor (Lo, et al., 1984; Vartak et al., 1997) as well as Anaerobic Sequencing Batch Reactor (ASBR) (Ndegwa et al., 2008); improving substrate composition by codigesting with others substrate (Callaghan et al., 1999; Gelegenis et al., 2007; Lehtomaki et al., 2007); and controlling ammonia inhibition (Nielsen and Angelidaki, 2008).

Different with other researchers mentioned before, an effort to improve methane yield was carried out by increasing the inoculums content in biodigester (Luengo and Alvarez, 1988; Castillo et al., 1995; (Sans, C. et al. 1995; Lopes, W. S. et al. 2004; Forster-Carneiro, T. et al. 2008). Several results from these study i.e inoculums are substantially relevant in process kinetics of biogas production (Luengo and Alvarez, 1988); amount of methane produced seemed proportional to the initial cattle manure as inoculums (Castillo et al., 1995); a strong influence of the bovine rumen fluid inoculums on anaerobic biostabilization of fermentable organic fraction of municipal solid waste (Lopes et al., 2004); and the higher percentage of inoculums gave the higher production of biogas (Forster-Carneiro et al., 2008). However, almost all of AD studied before, inoculums used were dominated by digested sludge from anaerobic digester. In addition, until right now, data concerning the study of the effect of inoculums content to biogas production rate are very limited.

Due to the highly anaerobic bacteria content in the rumen of the ruminant animals (Aurora, 1983) and the abundance of rumen waste disposal from slaughterhouse, this study focuses on the use of rumen fluid as inoculums in anaerobic digestion of cattle manure. Biogas production with cattle manure as substrate on slaughterhouse has special condition that rumen as inoculums is supplied continuously from rumen waste disposal. To our best knowledge, so far there is very limited academic literature available on using rumen fluid as inoculums in anaerobic digestion of cattle manure. The aim of 
the current work was to obtain more data on the digestion characteristics of the cattle manure under different temperatures and different feed to inoculums $(\mathrm{F} / \mathrm{I})$ ratios to biogas production.

\section{MATERIALS AND METHODS}

Sample preparation. The cattle manures and rumen fluids used in this research were taken randomly from slaughterhouse located on Semarang city. The fresh raw manure was collected from animal holding pen unit while rumen was collected from evisceration unit. Rumen fluid was prepared as follows: rumen content is poured to $100 \mathrm{~L}$ tank and added 25 liter tap water. Solid content then be separated from slurry by filter cloth. To assure that solid content in solution are dominated by bacteria, solution obtained then be filtered by 10 micron cartridge filter. Before using, all of raw manure collected is homogenized by mixing with propeller mixer. Raw manure and rumen fluid sample was analyzed its dry matter (DM) and volatile solid (VS) content by mean heating at 105 and $600{ }^{\circ} \mathrm{C}$, respectively. DM and VS content of fresh cattle manure and rumen fluid are presented in Table 1.

TABLE 1.

DM AND VS CHARACTERISTICS OF FRESH CATTLE MANURE AND RUMEN FLUID

\begin{tabular}{cccc}
\hline Parameter & Unit & $\begin{array}{c}\text { Fresh } \\
\text { manure }\end{array}$ & $\begin{array}{c}\text { Rumen } \\
\text { fluid }\end{array}$ \\
\hline DM & $\%$ & 22.75 & 1.3 \\
VS & $\%$ & 19.49 & 1.04 \\
VS/DM & $\%$ & 85.57 & 80 \\
\hline
\end{tabular}

Experimental apparatus set up. A series laboratory test of $400 \mathrm{ml}$ biodigester was operated in batch system. The main experiment apparatus consists of biodigester and biogas measurement. Biodigester were made from polyethylene bottle plugged with tightly rubber plug and was equipped with valve for biogas measurement. The temperature of biodigester was maintained at certain value thermostatically controlled electrically heated water bath. Biogas formed was measured by 'liquid displacement method' as also has been used by Yetilmezsoy and Sakar (2008). The schematic diagram of experimental laboratory set up as shown in Figure 1.

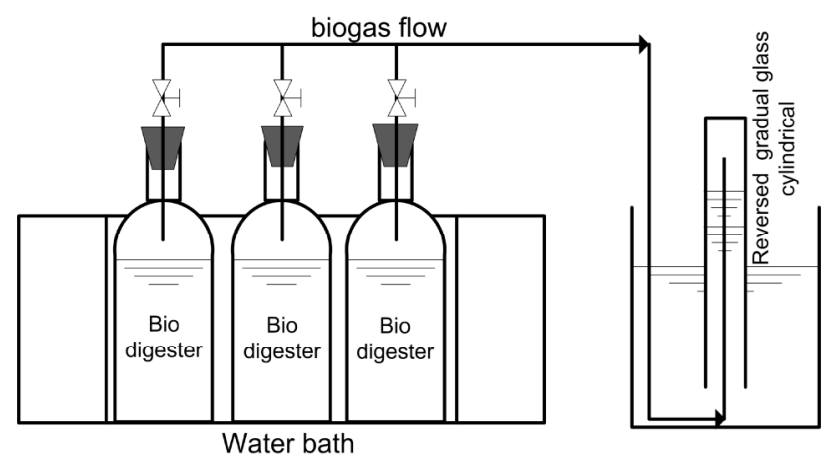

Figure 1. Schematic diagram of series laboratory batch assessment of anaerobic digestion

Experimental design. The influence of F/I ratio to biogas production rate was studied by varying manure, water, and rumen fluid ratio (MWR ratio) giving F/I from 0 to 70.54 .
Given 100 grams of fresh cattle manure was fed to each biodigester and mixed with rumen fluid and tap water resulting five different feed to inoculum (F/I) ratios (i.e. 17.64, $23.51,35.27$, and 70.54). Operating temperature was varied at room temperature. The biodigester performance was measured with respect to cumulative volume of biogas produced after corrected to standard pressure $(760 \mathrm{~mm} \mathrm{Hg}$ ) and temperature 0 ${ }^{\circ} \mathrm{C}$. All of treatment was carried by triplication. Composition of six manure samples used in the study as presented in Table 2.

TABLE 2. The Calculation OF F/M Ratio

\begin{tabular}{lccccc}
\hline \multicolumn{1}{c}{ Variables } & $\begin{array}{c}\text { Manure, } \\
\text { gram }\end{array}$ & $\begin{array}{c}\text { Rumen } \\
\text { Fluid, } \\
\text { ml }\end{array}$ & $\begin{array}{c}\text { Water, } \\
\text { ml }\end{array}$ & $\begin{array}{c}\text { \%o } \\
\text { Rumen } \\
\text { fluid }\end{array}$ & $\begin{array}{c}\text { F/M } \\
\text { ratio }\end{array}$ \\
\hline $\begin{array}{l}\text { Neat Rumen } \\
\text { fluid }\end{array}$ & 0 & 100 & 0 & 100 & 0.00 \\
MR11 & 100 & 100 & 0 & 50 & 17.60 \\
MWR12575 & 100 & 75 & 75 & 37.5 & 23.46 \\
MWR 155 & 100 & 50 & 50 & 25 & 35.19 \\
MWR 17525 & 100 & 25 & 75 & 12.5 & 70.39 \\
MW11 & 100 & 0 & 100 & 0 & - \\
\hline
\end{tabular}

Remarks: TS and VS of neat rumen fluid was 1.3 and $1.14 \%$, respectively; TS and VS of cattle manure was 22.7 and $20.06 \%$.

The experimental procedures. The certain $\mathrm{F} / \mathrm{I}$ ratio as research variables was fed to biodigester and homogenized with mixer propeller. $\mathrm{CO}_{2}$ gas was bubbled to biodigester to assure that biodigester in anaerobic condition. Biogas formed was measured every two days and stopped after biogas produced insignificantly. The similar procedure was performed in three replications

Statistical data analysis. Significance difference between treatments was determined by Duncan Multiple Range Test (DMRT).

\section{RESULTS AND DISCUSSIONS}

The effect of F/I ratio to biogas production was studied by varying TS from 17.64 to 70.54 . The F/I ratio was presented as ration between VS of feed and VS of inoculum used. The research was carried out in triplication. The data obtained from the study then is averaged and the cumulative volume of biogas production per total VS added (specific biogas production) was observed during 90 days as depicted in Figure 2. Numerical values of biogas yield in several days observation time is presented in Table 3.

Fig. 2 shows that, in general, substrates consist of manure and rumen fluid (F/I of 17.6 to 70.4) exhibit higher cumulative biogas production than substrates just contain manure and water (no inoculum). In the 80 days observation, biogas production of $17.64,23.51,35.27$, and $70.54 \mathrm{~F} / \mathrm{I}$ are 112.5; 144,$48 ; 162.18$; and $191.38 \mathrm{ml} / \mathrm{gVS}$, respectively. While sample with $0 \%$ inoculum give biogas production of 68.61 $\mathrm{ml} / \mathrm{gVS}$. In the fisrt 50 days observation, there is no significant differences between 17.64, 23.51, 35.27 of $\mathrm{F} / \mathrm{I}$ ( $\mathrm{P}>0.05)$. While sample of $70.54 \mathrm{~F} / \mathrm{I}$ the significant differences in biogas production with samples of 17.64, 23.51, 35.27 of F/I as well as $0 \%$ of inoculum $(\mathrm{P}<0.05)$. These result suggest that the 
optimum $\mathrm{F} / \mathrm{I}$ for giving the best performance of biogas production is in the range of 17.64 to 35.27 (correspond to 25 $-50 \%$ of rumen fluid).

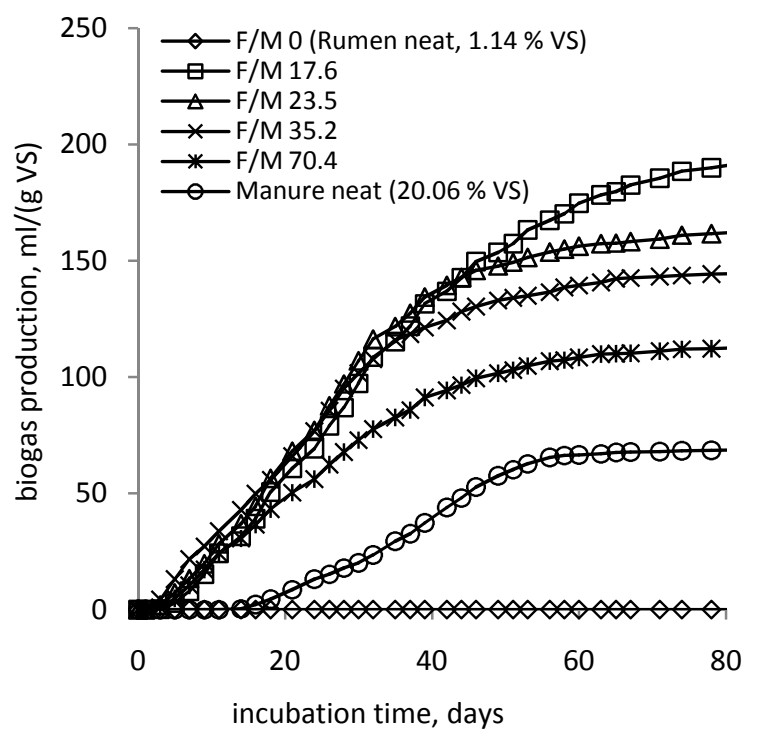

Figure 2. The effect of F/M ratio to biogas production; room temperature; TS and VS of rumen fluid was 1.3 and $1.14 \%$, respectively; TS and VS of cattle manure was 22.7 and $20.06 \%$

TABLE 3.

BIOGAS YIELD IN SEVERAL DAYS INCUBATION TIME

\begin{tabular}{|c|c|c|c|c|c|c|}
\hline \multirow{2}{*}{$\begin{array}{l}\text { Inc. } \\
\text { time } \\
\text { days }\end{array}$} & \multicolumn{6}{|c|}{$\mathrm{F} / \mathrm{I}$ ratio } \\
\hline & $\begin{array}{c}\text { Manure } \\
\text { neat }\end{array}$ & 70.4 & 35.2 & 23.5 & 17.6 & 0 \\
\hline 0 & 0.00 & 0.00 & 0.00 & 0.00 & 0.00 & 0.00 \\
\hline 10 & 0.07 & 24.19 & 33.62 & 28.33 & 24.15 & 0.00 \\
\hline 20 & 8.66 & 50.38 & $\begin{array}{l}65.92 \\
101.5\end{array}$ & $\begin{array}{l}68.01 \\
106.9\end{array}$ & 60.79 & 0.00 \\
\hline 30 & 20.02 & 73.00 & $\begin{array}{c}8 \\
121.3\end{array}$ & $\begin{array}{c}1 \\
134.3\end{array}$ & $\begin{array}{l}97.38 \\
131.5\end{array}$ & 0.00 \\
\hline 40 & 37.29 & $\begin{array}{l}91.21 \\
103.1\end{array}$ & $\begin{array}{c}9 \\
134.0\end{array}$ & $\begin{array}{c}1 \\
149.3\end{array}$ & $\begin{array}{c}8 \\
157.3\end{array}$ & 0.00 \\
\hline 50 & 60.29 & $\begin{array}{c}1 \\
108.3\end{array}$ & $\begin{array}{c}6 \\
139.4\end{array}$ & $\begin{array}{c}5 \\
156.2\end{array}$ & $\begin{array}{c}3 \\
174.6\end{array}$ & 0.00 \\
\hline 60 & 66.42 & $\begin{array}{c}6 \\
111.0\end{array}$ & $\begin{array}{c}6 \\
143.1\end{array}$ & $\begin{array}{c}3 \\
159.3\end{array}$ & $\begin{array}{c}5 \\
185.3\end{array}$ & 0.00 \\
\hline 70 & 67.85 & $\begin{array}{c}5 \\
112.5\end{array}$ & $\begin{array}{c}4 \\
144.4\end{array}$ & $\begin{array}{c}2 \\
162.1\end{array}$ & $\begin{array}{c}9 \\
191.3\end{array}$ & 0.00 \\
\hline 80 & 68.61 & 0 & 8 & 8 & 8 & 0.00 \\
\hline
\end{tabular}

Similar to these results, Lopes et al. (2004) reported that (a). no substantial difference was in evidence when $5 \%$ and $10 \%$ of the inoculum were used in preparation of the substrate; (b). in the range of 0 to $15 \%$ rumen fluid tested, the sample with the highest rumen content (15\%) gave the highest biogas production. Unfortunately, Lopes el at. (2004) is not extensively investigate yet in using inoculums content more than $15 \%$. Hence, of course this study doesn't give data concerning optimum content of inoculums for biogas production. On the other hand, according Foster-Carneiro et al. (2008), when treated food waste restaurant with $20-30 \%$ inoculums, the best performance for food waste biodegradation and methane generation was the reactor with
$30 \%$ of inoculums. However, we can not conclude this $30 \%$ inoculums is the optimum condition because the research is not extensively investigate yet in using inoculums content more than $30 \%$.

Relatively different with other samples, samples with 17.6 of F/I (50\% of rumen fluid) exhibit still there is the tendency to increase biogas production after 90 days observation. This is suggest that, in case of very abundance of rumen fluid such as occur in slaughtrehouse, the rumen fluid content of $50 \%$ (Manure : Rumen fluid ratio 1:1) will give the best performance for biogas production.

From Fig. 2 also can be seen that after 90 days observation still there is the tendency to increase biogas production and don't stop yet. This is predicted that the carbons contained by all of waste constituents are not equally degraded or converted to biogas through anaerobic digestion. According to Richard (1996) and Wilkie (2005), anaerobic bacteria do not or very slow degrade lignin and some other hydrocarbons. In other word, the higher lignin content will lower biodegradability of waste. Animal manure such as waste used in this study include lignocellulosic rich materials, so anaerobically degradation also rather unoptimum (Nielsen, et al., 2004). Even, in other case, AD of organic matter such as municipal solid waste will not stop completely after 360 days observation (Lopes et al., 2004).

From Fig. 2 also can be seen that rumen neat (100\% of rumen fluid) do not contribute the biogas production. Hence, all of biogases produced during all of treatment are originated only from substrate contained by manure. The substrate content by rumen fluid estimated has been degraded to biogas durung storage. This is because rumen fluid used in this research has been stored in several months. However, although rumen fluid has been stored in several months, is predicted there is no deterioration in activities of microorganism contained. This is suitable with the information of Rajeswari (2000) and Speece (1996) that decay rate of anaerobic bacteria is very low below $45{ }^{\circ} \mathrm{C}$. Even, anaerobic biomass can be preserved for months or years without serious deterioration in activity.

Finally, the conclusion can be drawn from this research that the best performance of biogas production will be obtained if $\mathrm{F} / \mathrm{I}$ ratio is in the range of 17.64 to 35.27 (correspond to $25-50 \%$ of rumen fluid). Decreasing of F/Is ratio will also increase biogas production. Due to the optimum TS content for biogas production between 7-9 \% (or correspond to more and less manure and total liquid 1:1) (Balsam, 2006; Baserja, 1984; and Zennaki et al., 1996), the rumen fluid content until $50 \%$ will give the best performance for biogas production. However, intensively research need to be carried in further research to study interaction effect of TS and rumen content to biogas production. The further research was directed to verify the effect of TS content to biogas production.

\section{CONCLUSIONS}

The effect of $\mathrm{F} / \mathrm{I}$ ratio to biogas production was studied by performing a series laboratory experiment using rumen fluid of animal ruminant as inoculums. The most important finding from this research is that the best performance of biogas production will be obtained if $\mathrm{F} / \mathrm{I}$ ratio is in the range of 17.64 to 35.27 (correspond to $25-50 \%$ of rumen fluid). The effec of rumen fluid concentration to biogas production will 
need to be studied in the further step research. In addition, the future work will be carried out to study the dynamics of biogas production if both the rumen fluid inoculums and manure are fed in the continuous system.

\section{REFERENCES}

[1]. Alvarez, R. and G. Lide'n. 2008. The effect of temperature variation on biomethanation at high altitude, Biores. Technol. 99: 7278-7284

[2]. Angelidaki, I. and B.K Ahring. 1994. Anaerobic thermophilic digestion of manure at different ammonia loads: Effect of temperature. Water Research, 28(3): 727-731

[3]. Angelidaki, I. and W. Sanders. 2004. Assessment of the anaerobic biodegradability of macropullants. Rev. Environ. Sci. Bio./Technol. 3: 117-129

[4]. Aurora, S.P. 1983. Microbial Digestion in Ruminants. Indian Council of Agricultural Research, New Delhi

[5]. Balsam, J. 2006. Anaerobic digestion of animal wastes: factors to consider. ATTRA-national sustainable agriculture information service. United States Department of Agriculture's, USA

[6]. Callaghan, F.J., D.A.J. Wase, K. Thayanithy, and C.F. Forster. 1999. Co-digestion of waste organic solids - batch studies. Bioresource Technol. 67 (2), 117-122.

[7]. Castillo, R.T., P.L. Luengo, and J.M. Alvarez. 1995. Temperature effect on anaerobic of bedding manure in a one phase system at different inoculums concentration, Agriculture, Ecosystems and Environment, 54:55-66

[8]. Demirci, G. G. and G. N. Demirer. 2004. Effect of initial COD concentration, nutrient addition, temperature and microbial acclimation on anaerobic treatability of broiler and cattle manure, Bioresource Technology 93: 109-117

[9]. Forster-Carneiro, T., M. Pérez and L. I. Romero. 2008. Influence of total solid and inoculum contents on performance of anaerobic reactors treating food waste. Bioresource Technology 99(15): 6994-7002.

[10]. Gelegenis, J., D. Georgakakis, I. Angelidaki, V. Mavris. 2007. Optimization of biogas production by co-digesting whey with diluted poultry manure. Renewable Energy, 32(13): 2147-2160

[11]. Ghaly, E and E. A. Echiegu. 1993. Performance evaluation of an intermittent flow continuous mix anaerobic reactor operating on dairy manure. Biomass and Bioenergy, 4(3):185-197

[12]. Hansen, K.H., I. Angelidaki, and B. Ahring. 1999. Improving thermophilic anaerobic digestion of swine manure. Water Research. 33(8): 1805-1810

[13]. Hansen, K.H., I. Angelidaki, B. Ahring. 1998. Anaerobic digestion of swine manure: inhibition by ammonia. Water research, 32(1): 5-12

[14]. Hansen, T.L., J. E. Schmidt, I. Angelidaki, E. Marca, J. C. Jansen, H. Mosbæk, T. H. Christensen. 2004. Method for determination of methane potentials of solid organic waste, Waste Management, 24(4):393-400

[15]. Hartmann, H., Angelidaki, I., Ahring, B.K. 2000. Increase of anaerobic degradation of particulate organic matter in full-scale biogas plants by mechanical maceration. Wat. Sci. Technol. 41, 145-153

[16]. Kaparaju, P. and Angelidaki, I., 2008. Effect of temperature and microbial activity on passive separation of digested cattle manure. Bioresour. Technol. 99: 1345-1352

[17]. Kaparaju, P., Buendía, I., Ellegaard, L., Angelidaki, I., 2008. Effects of mixing on methane production during thermophilic anaerobic digestion of manure: labscale and pilot-scale studies. Bioresour. Technol. 99: 4919-4928

[18]. Kaparaju, P., L. Ellegaard, I. Angelidaki. 2009. Optimisation of biogas production from manure through serial digestion: Lab-scale and pilotscale studies, Biores. Technol. 100: 701-709

[19]. Kaparaju, P.L.N., Rintala, J.A., 2008. Effects of solid-liquid separation on recovering residual methane and nitrogen of a digested dairy cattle manure. Bioresour. Technol. 99: 120-127.

[20]. Karakashev, D., Batstone, D.J., Angelidaki, I., 2005. Influence of the environmental conditions on the methanogenic composition of anaerobic biogas reactors. Appl. Environ. Microbiol. 71: 331-338.

[21]. Karim, K., R. Hoffmann, K. T. Klassonb, M.H. Al-Dahhan. 2005. Anaerobic digestion of animal waste: Effect of mode of mixing, Water Research 39: 3597-3606

[22]. Kashyap, D.R., K.S. Dadhich, S.K. Sharma. 2003. Biomethanation under psychrophilic conditions: a review, Biores. Technol. 87: 147-153

[23]. Kayhanian, M. and D. Rich. 1995. Pilot-scale high solids thermophilic anaerobic digestion of municipal solid waste with an emphasis on nutrient requirements, Biomass and Bioenergv, 8(6): 433-444.
[24]. Krylova, N.I., R.E. Khabiboulline, R.P. Naumova, and M.A. Nagel, M.A. 1997. The influence of ammonium and methods for removal during the anaerobic treatment of poultry manure. J. Chem. Technol. Biotechnol. 70 (1): 99-105

[25]. Lehtom“aki, A., S. Huttunen, J.A. Rintala. 2007. Laboratory investigations on co-digestion of energy crops and crop residues with cattle manure for methane production: Effect of crop to manure ratio, Resources, Conservation and Recycling, 51: 591-609

[26]. Liao, P.H., K.V. Lo, S.T. Chieng. 1984. Effect of liquid-solids separation on biogas production from dairy manure. Energy in Agriculture, 3: 61-69

[27]. Liu, D., D. Liu, R.J. Zeng, I. Angelidaki. 2006. Hydrogen and methane production from household solid waste in the two-stage fermentation process. Water Research, 40(11): 2230-2236

[28]. Lo, K.V., A. J. Whitehead, P. H. Liao, N. R. Bulley. 1984. Methane production from screened dairy manure using a fixed-film reactor. Agricultural Wastes, 9(3): 175-188

[29]. Lopes, W. S., V. D. Leite and S. Prasad (2004). Influence of inoculum on performance of anaerobic reactors for treating municipal solid waste. Bioresource Technology 94(3): 261-266

[30]. Luengo, P.L. and J. M. Alvarez. 1988. Influence of temperature, buffer, composition and straw particle length on the anaerobic digestion of wheat straw-pig manure mixtures. Resources, Conservation and Recycling, 1(1): 27-37

[31]. Møller, H.B., A.M. Nielsen, R. Nakakubo, H.J. Olsen. 2008. Process performance of biogas digesters incorporating pre-separated manure, Livestock Science, 112: 217-223

[32]. Muryanto, J. Pramono, Suprapto, K. Ekaningtyas, dan Sudadiyono. 2006. Biogas, Energi Alternatif Ramah Lingkungan. Cetakan 1, Balai Pengkajian Teknologi Pertanian (BPTP) Jawa Tengah, Ungaran

[33]. Ndegwa, P.M., D.W. Hamilton, J.A. Lalman, and H.J. Cumba. 2008. Effects of cycle-frequency and temperature on the performance of anaerobic sequencing batch reactors (ASBRs) treating swine waste, Bioresource Technology, 99: 1972-1980

[34]. Nielsen, H.B. and I. Angelidaki. 2008. Strategies for optimizing recovery of the biogas process following ammonia inhibition. Bioresource Technology. 99(17):7995-8001

[35]. Nopharatana, A., P. C. Pullammanappallil, W. P. Clarke. 2007. Kinetics and dynamic modeling of batch anaerobic digestion of municipal solid waste in a stirred reactor, Waste Management, 27: 595-603

[36]. Okkerse, C. and H. V. Bekkum. 1999. From fossil to green. Green Chem., 1: 107-114

[37]. Safley, Jr. L.M., R.L. Vetter and D. Smith. 1987. Operating a full-scale poultry manure anaerobic digester. Biological Wastes, 19(2): 79-90

[38]. Safley, Jr.L.M. and P.W. Westerman. 1992. Performance of a dairy manure anaerobic lagoon. Bioresource Technology, 42(1): 43-52

[39]. Safley, L.M. and Westerman, P.W., 1992. Performance of a low temperature lagoon digester. Biores. Technol. 41: 167-175

[40]. Sans, C., J. Mata-Alvarez, F. Cecchi, P. Pavan and A. Bassetti (1995). Acidogenic fermentation of organic urban wastes in a plug-flow reactor under thermophilic conditions. Bioresource Technology 54(2): 105-110

[41]. Sarapatka, B. 1993. A study of biogas production during anaerobic fermentation of farmyard manure. Biomass and Bioenergy, 5(5): 387393

[42]. Vartak, D.R., C. R. Engler, M. J. McFarland, and S. C. Ricke. 1997. Attached-film media performance in psychrophilic anaerobic treatment of dairy cattle wastewater, Bioresource Technology 62: 79-84

[43]. Webb, A.R. and F.R. Hawkes. 1985. Laboratory scale anaerobic digestion of poultry litter: Gas yield-loading rate relationships. Agricultural Wastes, 13(1): 31-49

[44]. Webb, A.R. and F.R. Hawkes. 1985. The anaerobic digestion of poultry manure: Variation of gas yield with influent concentration and ammonium-nitrogen levels. Agricultural Wastes, 14(2): 135-156

[45]. Wenxiu, T. and W. Mengjie. 1989. Experiment and research on a mesophilic anaerobic digester with dairy cattle manure in Northern China. Biomass. 20(1-2): 41-52 